\title{
Letter \\ Role of the eosinophil count in discriminating the severity of
community-acquired pneumonia in HIV-infected patients
}

Rafel Perelló ${ }^{1}$ Oscar Miró1, Josep M Miró ${ }^{\text {and Asunción Moreno }}{ }^{2}$

\begin{abstract}
${ }^{1}$ Emergency Department, Hospital Clinic of Barcelona, Institut d'Investigacions Biomèdiques Agustí Pi i Sunyer, University of Barcelona, Villarroel 170 , 08036 Barcelona, Catalonia, Spain

${ }^{2}$ Infectious Diseases Service, Hospital Clínic of Barcelona, Institut d'Investigacions Biomèdiques Agustí Pi i Sunyer, University of Barcelona, Villarroel

170, 08036 Barcelona, Catalonia, Spain
\end{abstract}

Corresponding author: Rafel Perelló, rperello@clinic.ub.es

Published: 13 August 2008

This article is online at http://ccforum.com/content/12/4/425

Critical Care 2008, 12:4?? (doi:10.1186/cc6971)

(c) 2008 BioMed Central Ltd

See related research by Abidi et al., http://ccforum.com/content/12/2/R59

Abidi and colleagues recently reported that eosinopenia constitutes a good diagnostic marker in distinguishing between noninfection and infection, but is a moderate marker in discriminating between systemic inflammatory response syndrome and infection in newly admitted critically ill patients [1]. They propose that eosinopenia may become a helpful clinical tool in intensive care unit (ICU) practices. They included different types of severe infections, however, and therefore the utility of eosinopenia for a particular kind of infection is not approached.

We would like to describe our experience with a homogeneous group of HIV-infected patients suffering from community-acquired pneumonia (CAP), a severe clinical condition that sometimes can lead the patient to the ICU. We consecutively included $137 \mathrm{HIV}$-infected patients with a firm diagnosis of CAP based on Infectious Diseases Society of America criteria, whose clinical, analytical and outcome data were prospectively recorded. We split our series into different groups depending on the patient requiring ICU admission $(n=29)$ or not requiring ICU admission $(n=108)$, and depending on inhospital patient survival $(n=132)$ or inhospital death $(n=5)$.

The results are presented in Table 1. As can be seen, eosinopenia was not associated with a higher ICU admission rate or with higher mortality. Accordingly, we believe that the total eosinophil count and/or eosinopenia have little (if any) value in predicting the severity of CAP in HIV-infected patients.

Table 1

Relationship between some analytical parameters and severity of community-acquired pneumonia in HIV-infected patients ${ }^{a}$

\begin{tabular}{|c|c|c|c|c|c|c|}
\hline & \multicolumn{3}{|c|}{ ICU admission } & \multicolumn{3}{|c|}{ Mortality } \\
\hline & No & Yes & $P$ value* & Discharged alive & Death & $P$ value* \\
\hline C-reactive protein (mg/dl) & $16.3 \pm 12.6$ & $18.8 \pm 12.1$ & 0.26 & $17.2 \pm 12.7$ & $10.7 \pm 14.0$ & 0.22 \\
\hline Total leukocyte count (cells/ml) & $10,410 \pm 5,810$ & $14,100 \pm 9,820$ & 0.08 & $11,230 \pm 7,120$ & $7,580 \pm 3,902$ & 0.25 \\
\hline Total eosinophil count (cells/ml) & $114 \pm 155$ & $114 \pm 145$ & 0.68 & $115 \pm 159$ & $98 \pm 31$ & 0.43 \\
\hline Eosinopenia $(<40$ cells/ml) & & & 0.94 & & & 0.59 \\
\hline No & $85(79 \%)$ & $22(76 \%)$ & & $112(77 \%)$ & $5(100 \%)$ & \\
\hline Yes & $23(21 \%)$ & $7(24 \%)$ & & $30(27 \%)$ & $0(0 \%)$ & \\
\hline
\end{tabular}

aSeverity of community-acquired pneumonia judged by the need for intensive care unit (ICU) admission and by mortality. Data presented as the mean \pm standard deviation or $n(\%)$. ${ }^{*}$ Calculated by means of the Mann-Whitney nonparametric test (quantitative variables) and the chi-square test or Fisher's exact test (qualitative variables).

$\mathrm{CAP}=$ community-acquired pneumonia; $\mathrm{ICU}=$ intensive care unit. 
From the emergency department point of view - departments that usually are overcrowded [2] - any tool that allows the physicians to better approach the severity of the infections in general, and the severity of the HIV-infected patients developing CAP in particular, would be welcomed $[3,4]$. Eosinophils seem to fail to fulfil this commitment, while other classic analytical markers, such as the total leukocyte count or C-reactive protein values, remain with greater prognostic value [5].

\section{Acknowledgement}

The authors thank Red Española de Investigación en Patología Infecciosa.

\section{Authors' response}

Khalid Abidi, Ibtissam Khoudri, Jihane Belayachi, Naoufel Madani, Aicha Zekraoui, Amine Ali Zeggwagh and Redouane Abouqal

We thank the editor for giving us the opportunity to respond to the comments raised by Dr Perello and colleagues. In our experience, eosinopenia is a good marker for the diagnosis of sepsis on ICU admission [1]. It discriminates well between noninfected patients and infected patients. Our study population did not include HIV-infected patients. Moreover, the prognostic value of eosinopenia was not tested. We therefore cannot ascertain the value of this marker to predict mortality in the ICU.

Concerning the severity of infection, Perello and colleagues found no association between eosinopenia and a higher ICU admission rate among HIV-infected patients suffering from CAP. This finding was also reported in our work involving a diverse group of critically ill adults admitted to the ICU. The lack of differences between sepsis, severe sepsis and septic shock was noted in our study. This was not surprising because of the suggested floor effect of eosinopenia.

Furthermore, in the study of Perello and colleagues there was no noninfection group enrolled (HIV patients without CAP) to test the value of eosinopenia in the diagnosis of sepsis (CAP) among HIV-infected patients. Gil and colleagues showed in an internal medicine department that inflammatory syndrome associated with eosinophils $<40 \mathrm{cells} / \mathrm{mm}^{3}$ is related to bacterial infectious diseases [6]. If we take into account the hypothetical mechanism of eosinopenia, which is the migration of eosinophils to the inflammatory site $[7,8]$, we think it may be interesting if Perello and colleagues used the eosinophil cutoff value $(40 \mathrm{cells} / \mathrm{ml})$ to test the value of eosinopenia in distinguishing HIV-infected patients with CAP and those without CAP.

\section{Competing interests}

The authors declare that they have no competing interests.

\section{References}

1. Abidi K, Khoudri I, Belayachi J, Madani N, Zekraoui A, Zeggwagh AA, Abouqal R: Eosinopenia is a reliable marker of sepsis on admission to medical intensive care units. Crit Care 2008, 12: R59.

2. Francis RC, Spies $C D$, Kerner T: Quality management and benchmarking in emergency medicine. Curr Opin Anaesthesiol 2008, 21:233-239.

3. Gil León C, Garcia-Castrillo Riesgo L, Moya Mir MS, Artigas Raventós A, Borges Sa M, Candel González FJ, Chanovas Borras $M$, Ferrer Roca R, Julián Jiménez A, Loza Vazquez A, Sánchez García M: Documento de Consenso (SEMES-SEMICYUC). Recomendaciones del manejo diagnóstico-terapéutico inicial y multidisciplinario de la sepsis grave en los Servicios de Urgencias Hospitalarios. Emergencias 2007, 19:260-272.

4. Arias Rodríguez D, López Izquierdo R, Gómez Rodríguez D, Del Rey Vieira A: Marcadores pronósticos precoces en el paciente infectado. Emergencias 2007, 19:290-291.

5. Castelli GP, Pognani C, Meisner M, Stuani A, Bellomi D, Sgarbi L: Procalcitonin and $C$-reactive protein during systemic inflammatory response syndrome, sepsis and organ dysfunction. Crit Care 2004, 8:R234-R242.

6. Gil H, Magy N, Mauny F, Dupond JL: Value of eosinopenia in inflammatory disorders: an 'old' marker revisited. Rev Med Interne 2003, 24:431-435.

7. Bass DA, Gonwa TA, Szejda P, Cousart MS, DeChatelet LR, McCall CE: Eosinopenia of acute infection: production of eosinopenia by chemotactic factors of acute inflammation. J Clin Invest 1980, 65:1265-1271.

8. Rothenberg ME: Eosinophilia. N Engl J Med 1998, 338:15921600 . 